\title{
Toxicity symptoms of nickel in common bean ${ }^{1}$
}

\author{
Sintomas de toxidez de níquel em feijoeiro
}

\author{
Marcela Campanharo $^{2 *}$, Pedro Henrique Monnerat ${ }^{3}$, Marcelo Curitiba Espindula ${ }^{4}$, Wanderson Souza Rabello S $^{3}$ \\ Guilherme Ribeiro ${ }^{3}$
}

\begin{abstract}
Despite the importance of nickel (Ni) in the N metabolism of legumes, common bean (Phaseolus vulgaris L.) is considered very sensitive to $\mathrm{Ni}$ doses. The objective in this study was to characterize the toxicity symptoms of Ni in common bean cv. Pérola. The experiment was conducted in greenhouse in the campus of the Universidade Estadual do Norte Fluminense - Darcy Ribeiro, Campos dos Goytacazes - RJ. Solutions containing 0; 20; 40; 60 and $100 \mathrm{mg} \mathrm{L}^{-1}$ of $\mathrm{Ni}$, in the form of nickel chloride hexahydrate $\left(\mathrm{NiCl}_{2} \cdot 6 \mathrm{H}_{2} \mathrm{O}\right)$, were applied to shoots of common bean plants at the rate of $2.5 \mathrm{~mL}$ of solution per plant of common bean, 25 days after sowing. Plants of common bean treated with $0 ; 20 ; 40$ and $60 \mathrm{mg} \mathrm{L}^{-1}$ of Ni showed no toxicity symptoms. Plants treated with $100 \mathrm{mg} \mathrm{L}^{-1}$ of Ni showed chlorotic leaves with gray spots that coalesced and became necrotic in a more advanced stage.
\end{abstract}

Keywords - Phaseolus vulgaris L. Chlorosis. Necrosis.

Resumo - Apesar de o Ni ser importante no metabolismo do N em leguminosas, o feijoeiro comum (Phaseolus vulgaris L.) é considerado bastante sensível a doses de Ni. Objetivou-se caracterizar os sintomas de fitotoxidez de Ni em feijoeiro comum cv. Pérola. O experimento foi conduzido em casa de vegetação na Universidade Estadual do Norte Fluminense - Darcy Ribeiro, Campos dos Goytacazes - RJ. Foram aplicados 0; 20; 40; 60 e $100 \mathrm{mg} \mathrm{L}^{-1}$ de Ni (2,5 mL de solução por planta) na forma de cloreto de níquel hexahidratado $-\mathrm{NiCl}_{2} \cdot 6 \mathrm{H}_{2} \mathrm{O}$, na parte aérea de plantas de feijoeiro comum aos 25 dias após a semeadura. Plantas de feijão tratadas com 0;20; 40 e $60 \mathrm{mg} \mathrm{L}^{-1}$ de Ni não apresentaram sintomas de ftoxidez. Já as plantas que receberam a dose de $100 \mathrm{mg} \mathrm{L}^{-1}$ de $\mathrm{Ni}$ apresentaram folhas cloróticas e com manchas acinzentadas que coalesceram e se tornaram necróticas em um estádio mais avançado.

Palavras-chave - Phaseolus vulgaris L. Clorose. Necrose.

\footnotetext{
* Corresponding author

${ }^{1}$ Received 07/10/2009; accepted 28/06/2010

Part of the doctoral thesis of first author/UENF

${ }^{2}$ Gerência de Pesquisa e Difusão, FAPES, Vitória-ES, Brasil, marcelacampanharo@gmail.com

32Departamento de Produção Vegetal/UENF, Campos dos Goytacazes- RJ, Brasil, phmonnerat@yahoo.com.br, rabellosouza@hotmail.com,

guilherme.uenf@gmail.com

${ }^{4}$ Departamento de Fitotecnia/UFV, Viçosa-MG, Brasil, curitibaespindula@yahoo.com.br
} 


\section{Introduction}

Up until a few years ago, nickel (Ni) was not thought to be essential for plants, with research focusing on its toxic effect (GALDO et al., 2004; KOPITTKE et al., 2007). Studies sought to understand how Ni hyperaccumulator plants are capable of absorbing, accumulating and tolerating high concentrations of this element in their tissues aiming at the use of techniques such as phytoextraction to recover contaminated land (BROADSHURTS, 2009; GIORDANO et al., 2005; INGLE et al., 2005). However, the finding that $\mathrm{Ni}$ is a component of the enzyme urease, which is present in numerous plant species, has drawn scientific interest from researches relating to its role in higher plants. Since then, plant developmental responses to $\mathrm{Ni}$ fertilization have been obtained under field conditions (WOOD et al., 2004a, b e c) and in nutrient solutions (NEVES et al., 2007; TAN; IKEDA, 2000).

Reports on developmental responses to $\mathrm{Ni}$ application have become common, as well as the variability among plant species and even cultivars of the same species in requirements and tissue tolerance to Ni. Small Ni amounts ( 0.01 to $5 \mu \mathrm{g} \mathrm{g}^{-1}$ of dry matter) are enough to meet the needs of some higher plant species. However, high $\mathrm{Ni}$ concentrations can cause toxicity to plants (SEREGIN; KOZHEVNIKOVA, 2006) and even death, as verified by Berton et al. (2006), by applying $210 \mathrm{mg} \mathrm{kg} \mathrm{kg}^{-1}$ of nickel sulphate $\left(\mathrm{NiSO}_{4} \cdot 6 \mathrm{H}_{2} \mathrm{O}\right)$ in the soil.

Nickel toxic effects produce various injury symptoms, including development impairment, physiological disorders in the photosynthetic process, transport of photoassimilates, mineral nutrition, water potential of plants, chlorosis, necrosis and wilting (KRUPA et al., 1993; PANDEY; SHARMA, 2002).

Nickel stress interferes with the activity of superoxide dismutase, with possible accumulation of hydrogen peroxide $\left(\mathrm{H}_{2} \mathrm{O}_{2}\right)$ in leaf tissue. It has been suggested that $\mathrm{H}_{2} \mathrm{O}_{2}$ inhibits the growth of plants treated with heavy metal (CHEN et al. 2000), acting as a substrate for peroxidases involved in the hardening of cell walls, which leads to restrictions to cell elongation (DÍAZ et al., 2001).

In a study assessing the $\mathrm{Ni}$ effect on the content of reactive oxygen species and oxidative enzyme activity in leaves of wheat, Gajewska and Skolodowska (2007) reported that seedlings treated with $100 \mu \mathrm{M}$ of $\mathrm{Ni}$ accumulated $\mathrm{O}_{2}^{-}$and $\mathrm{H}_{2} \mathrm{O}_{2}$ in the leaf tissue. The increased content of reactive oxygen species was followed by inhibition in the activity of the enzymes superoxide dismutase and catalase, which are responsible for detoxifying hydrogen peroxide.

Despite the Ni importance for the $\mathrm{N}$ metabolism in legumes, common bean plants are considered very sensitive to $\mathrm{Ni}$ rates compared with other crops. Common bean plants have reduced yield significantly when the levels of $\mathrm{Ni}$ in the leaves were above $40 \mathrm{mg} \mathrm{kg}^{-1}$, as well as negative effect on levels of total chlorophyll caused by a lower $\mathrm{Mg}$ absorption by plants under high Ni doses (PICCINI; MALAVOLTA, 1992). In soil the dose $2.3 \mathrm{mg} \mathrm{kg}^{-1}$ of $\mathrm{Ni}$ as $\mathrm{NiSO}_{4} \cdot 6 \mathrm{H}_{2} \mathrm{O}$ was sufficient to increase the metal content of the grains above $5 \mathrm{mg} \mathrm{kg}^{-1}$ fresh matter and made them unfit for human consumption (BERTON et al., 2006).

The objective in this work was to characterize toxicity symptoms of nickel in common bean cv. Pérola.

\section{Materials and methods}

The experiment was conducted in a greenhouse at the Division of Plant Mineral Nutrition of the Universidade Estadual do Norte Fluminense - Darcy Ribeiro, Campos dos Goytacazes - RJ. Common bean cv. Pérola was used as test plant.

Samples of Dystrophic Red Yellow Tb Argisol were collected at 0-20 cm depths (TAB. 1).

Table 1 - Chemical characteristics of the Dystrophic Red Yellow Tb Argisol, Campos dos Goytacazes - RJ, 2008

\begin{tabular}{|c|c|c|c|c|c|c|c|c|c|c|c|}
\hline $\mathrm{pH}^{*}$ & $\mathrm{CE}$ & $\mathrm{P}$ & $\mathrm{K}$ & $\mathrm{Ca}$ & $\mathrm{Mg}$ & $\mathrm{Al}$ & $\mathrm{H}+\mathrm{Al}$ & $\mathrm{Na}$ & B & Mo & $\mathrm{Mn}$ \\
\hline & $\mu \mathrm{S}$ & \multicolumn{2}{|c|}{----- $\mathrm{mg} \mathrm{kg}^{-1}-----$} & \multicolumn{4}{|c|}{ 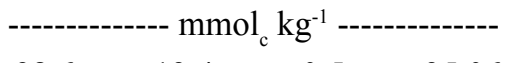 } & \multicolumn{4}{|c|}{---------------- $\mathrm{mg} \mathrm{kg}^{-1}$---------------' } \\
\hline 5.62 & 119.71 & 19 & 180 & 98.6 & 13.4 & 0.5 & 35.06 & 0.41 & 0.51 & 0.021 & 38.1 \\
\hline $\mathrm{Zn}$ & $\mathrm{Cu}$ & $\mathrm{Fe}$ & $\mathrm{Ni}$ & $\mathrm{S}$ & $\mathrm{C}$ & $\mathrm{MO}$ & $\mathrm{T}$ & $\mathrm{t}$ & SB & $\mathrm{V}$ & $\mathrm{mt}$ \\
\hline \multicolumn{5}{|c|}{---------------------- $\mathrm{mg} \mathrm{kg}^{-1}$---------------------- } & \multicolumn{2}{|c|}{------ $\mathrm{g} \mathrm{kg}^{-1}$------ } & \multicolumn{3}{|c|}{-------- mmol $\mathrm{kg}^{-1}$-------- } & \multicolumn{2}{|c|}{------- \% ------- } \\
\hline 3.8 & 0.59 & 86.9 & 0.23 & 4.60 & 13.51 & 23.59 & 152.08 & 117.52 & 117.02 & 77 & 0.42 \\
\hline
\end{tabular}

$*$ pH at $\mathrm{H}_{2} \mathrm{O} 1: 2.5$ 
The experiment was arranged in a randomized block design (RBD) with four replications. The treatments consisted of nickel concentrations at $0 ; 20 ; 40 ; 60$ and $100 \mathrm{mg} \mathrm{L}^{-1}$ ( $2.5 \mathrm{~mL}$ of solution per plant) in the form of nickel chloride hexahydrate $-\mathrm{NiCl}_{2} \cdot 6 \mathrm{H}_{2} \mathrm{O}$.

Plants development, mineral composition of stems and leaves, as well as, urea hydrolyses in those tissues were evaluated. However, in this work it will just be shown the characterization of the toxicity symptoms of nickel, observed in plants treated with $100 \mathrm{mg} \mathrm{L}^{-1}$ of Ni.

Each experimental unit consisted of a vase with $5-\mathrm{kg}$ soil capacity and four plants. Each Ni solution was added with the spreader-sticker adjuvant Adesil ${ }^{\circledR}$ $\left(0.2 \mathrm{~mL} \mathrm{~L}^{-1}\right)$ at the time of foliar spray. The Ni solution was applied twenty-five days after sowing, when plants were at the $\mathrm{V}_{4}$ stage, which is the vegetative stage when the third trifoliate leaf was fully expanded and the plant started branching.

\section{Results and discussion}

Plants of common bean treated with $0 ; 20 ; 40$ and $60 \mathrm{mg} \mathrm{L}^{-1}$ of Ni showed no toxicity symptoms. However, bean plants that received $100 \mathrm{mg} \mathrm{L}^{-1}$ of $\mathrm{Ni}$ showed visual symptoms of toxicity characterized by leaf chlorosis (FIG. 1). The toxicity symptoms were observed 24 hours after Ni application. The effects appeared in young and mature tissues with predominance and higher intensity in more mature tissues.

Leaf chlorosis observed may be due to the presence of $\mathrm{Ni}$, which at high levels can affect pigment accumulation in the plant, reflecting changes in the chlorophyll/ carotenoid ratio and chlorophyll $a / b$, in which carotenoids are more sensitive than chlorophyll, and chlorophyll $b$ is more susceptible than chlorophyll $a$. Thus, the evolution of this effect reaches the photosynthetic apparatus of the plant, interfering with the photochemical efficiency of photosystem II. Both photosystem I and II are inhibited by the Ni concentration, but the photosystem II is more strongly affected by disturbances in the Calvin cycle and the inhibition of electron transport, because of excessive amounts of ATP and NADPH accumulated by the inefficiency of reactions taking place in the dark phase (KRUPA et al., 1993).

Although the toxicity caused by heavy metals is widely studied in plants, the mechanisms of Ni toxicity still remain unclear. However, numerous evidences indicate that the $\mathrm{Ni}$ toxicity can be attributed also to oxidative stress at the cellular level (BACCOUCH et al., 2001; GONNELLI et al., 2001). Under stress conditions, including exposure to excessive concentrations of heavy metals, there is imbalance and removal of reactive oxygen

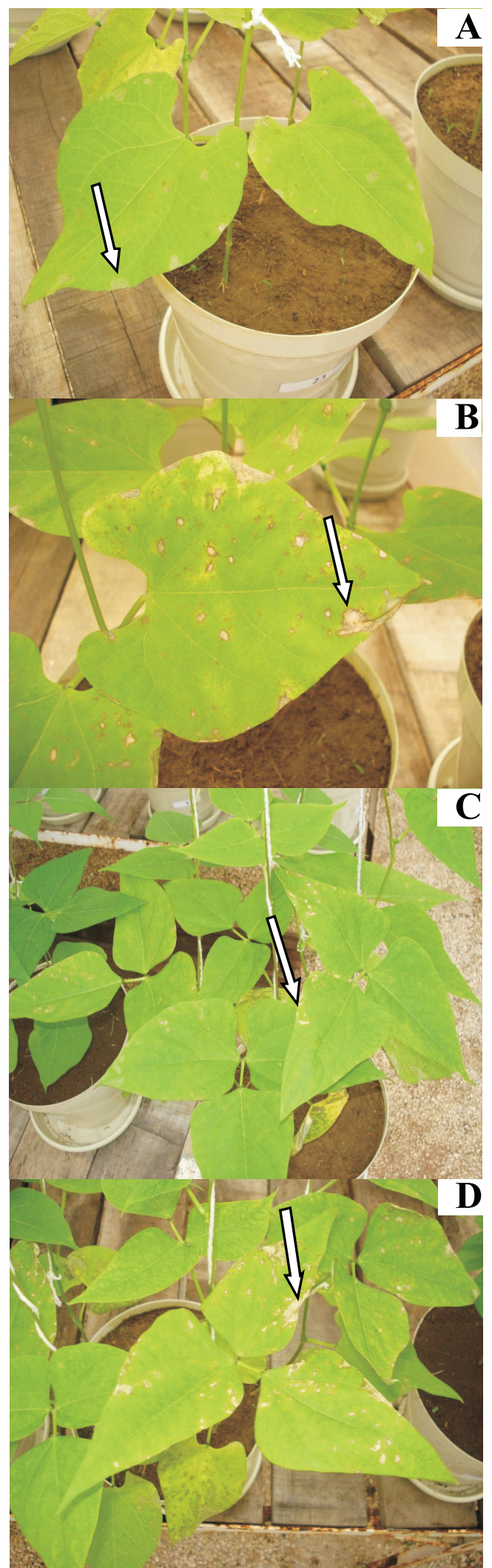

Figure 1 - Toxicity symptoms in common bean cv. Pérola grown in Red Yellow Tb Argisol after Ni foliar application of nickel. (A) Initial gray spots, (B, C and D) Chlorosis and necrosis 
species in plant tissues (GRATÃO et al., 2005; GRATÃO et al., 2008). This may consequently lead to oxidative damage of macromolecules such as lipids, proteins and nucleic acids (KEHRER, 2000).

Besides chlorosis, young leaves and/or mature leaves initially showed random and irregular gray spots in the limbo, which atmore advanced stages, coalesced and became necrotic. These results are similar to those reported by (PICCINI; MALAVOLTA, 1992) for common beans and may be related to hindering respiratory activity and denaturation of the cell protoplasm, which leads to tissue death in these areas.

\section{Conclusion}

Nickel toxicity in common bean plants is characterized by chlorotic leaves with gray spots that coalesce and become necrotic in a more advanced stage.

\section{Acknowledgements}

The authors would like to thanks to the Conselho Nacional de Desenvolvimento Científico e Tecnológico (CNPq) for the financial support to this study.

\section{References}

BACCOUCH, S.; CHAOUI, A.; EL FERJANI, E. Nickel toxicity induces oxidative damage in Zea mays roots. Journal of Plant Nutrition, v. 24, n. 07, p. 1085-1097, 2001.

BERTON, R. S. et al. Toxicidade do níquel em plantas de feijão e efeitos sobre a microbiota do solo. Pesquisa Agropecuária Brasileira, v. 41, n. 08, p. 1305-1312, 2006.

BROADHURST, C. L. et al. Interaction of nickel and manganese in accumulation and localization in leaves of the Ni hyperaccumulators Alyssum murale and Alyssum corsicum. Plant Soil, v. 314, p. 35-48, 2009.

CHEN, L. M.; LIN, C. C.; KAO, C. H. Copper toxicity in rice seedlings: Changes in antioxidative enzyme activities, $\mathrm{H}_{2} \mathrm{O}_{2}$ level, and cell wall peroxidase activity in roots. Botanical Bulletin of Academia Sinica, v. 41, n. 02, p. 99-103, 2000.

DÍAZ, J. et al. Induction of shikimate dehydrogenase and peroxidase in pepper (Capsicum annuum L.) seedlings in response to copper stress and its relation to lignification. Plant Science, v. 161, p. 179-188, 2001.

GAJEWSKA, E.; SKOLODOWSKA, M. Effect of nickel on ROS content and antioxidative enzyme activities in wheat leaves. BioMetals, v. 20, n. 01 p. 27-36, 2007.

GALDOS, M. V.; de MARIA, I. C.; CAMARGO, O. A. Atributos químicos e produção de milho em um Latossolo Vermelho eutroférrico tratado com lodo de esgoto. Revista Brasileira de Ciência do Solo, v. 28, p. 569-577, 2004.

GIORDANI, C.; ZANCHI, C. Phytoremediation of soil polluted by nickel using agricultural crops. Environmental Management, v. 36, n. 05 , p. 675-681, 2005.

GONNELLI, C.; GALARDI, F.; GABBRIELLI, R. Nickel and copper tolerance and toxicity in three Tuscan populations of Silene paradoxa. Physiologia Plantarum, v. 113, p. 507514, 2001.

GRATÃO, P. L. et al. Making the life of heavy metal-stressed plants a little easier. Funcional Plant Biology, v. 32, n. 06, p. 481-494, 2005.

GRATÃO, P. L. et al. Antioxidant response of Nicotiana tabacum cv. Brigtht Yellow 2 cells to cadmium and nickel stress. Plant Cell, Tissue and Organ Culture, v. 94, n. 01, p. 73-83, 2008.

INGLE, R. A. et al. Constitutively high expression of the histidine biosynthetic pathway contributes to nickel tolerance in hyperaccumulator plants. The Plant Cell, v. 17, p. 20892106, 2005.

KEHRER, J. P. The Haber-Weiss reaction and mechanisms of toxicity. Toxicology, v. 149, n. 01, p. 43-50, 2000.

KOPITTKE, P. M.; ASHER, C. J.; MENZIES, N. W. Toxic Effects of $\mathrm{Ni}^{2+}$ on Growth of Cowpea (Vigna unguiculata). Plant Soil, v. 292, n. 01/02, p. 283-289, 2007.

KRUPA, Z. et al. In vivo response of photosynthetic apparatus of Phaseolus vulgaris L. to nickel toxicity. Journal of Plant Physiology, v. 142, n. 06, p. 664-668, 1993.

NEVES, O. S. C. et al. Adição de níquel na solução nutritiva para o cultivo de mudas de umbuzeiro. Revista Brasileira de Ciência do Solo, v. 31, n. 03, p. 485-490, 2007.

PANDEY, N.; SHARMA, C. P. Effect of heavy metals $\mathrm{Co}^{2+}, \mathrm{Ni}^{2+}$ and $\mathrm{Cd}^{2+}$ on growth and metabolism of cabbage. Plant Science, v. 163, n. 04, p. 753-758, 2002.

PICCINI, D. F.; MALAVOLTA, E. Toxidade de níquel em arroz e feijão em solos ácidos. Revista Brasileira de Ciência do Solo, v. 16, p. 229-233, 1992.

SEREGIN, I. V.; KOZHEVNIKOVA, A. D. Physiological role of nickel and its toxic effects on higher plants. Russian Journal of Plant Physiology, v. 53, n. 02, p. 257-277, 2006.

SEREGIN, I. V.; KOZHEVNIKOVA, A. D. Enhancement of nickel and lead accumulation and their toxic growthinhibitory effects on amaranth seedlings in the presence of calcium. Russian Journal of Plant Physiology, v. 56, n. 01, p. 80-84, 2009.

SRIVASTANA, S. et al. Nickel phytoremediation potential of broad bean, Vicia faba L., and its biochemical responses. Bulletin of Environmental Contamination and Toxicology, v. 74, n. 04, p. 715-724, 2005.

TAN, X. W.; IKEDA, H. Effects of nickel concentration in the nutrient solution on the nitrogen assimilation and growth of 
tomato seedlings in hydroponic culture supplied with urea or nitrate as the sole nitrogen source. Scientia Horticulturae, v. 84, n. 03/04, p. 265-273, 2000.

WOOD, B. W.; REILLY, C. C.; NYCZEPIR, A. P. Mouse-ear of pecan: I. Symptomatology and occurrence. Hortscience, v. 39, n. 01, p. 87-94, 2004a.
WOOD, B. W.; REILLY, C. C.; NYCZEPIR, A. P. Mouse-ear of pecan: II. Influence of nutrient applications. Hortscience, v.3 9, n. 01, p. 95-100, 2004b.

WOOD, B. W.; REILLY, C. C.; NYCZEPIR, A. P. Mouse-ear of pecan: A nickel deficiency. Hortscience, v. 39, n. 01, p. 1238$1242,2004 \mathrm{c}$. 